\title{
VAIKŲ ŪMINIS SKAUSMAS: JO SAMPRATA, NEUROFIZIOLOGINIAI IR VERTINIMO YPATUMAI, VALDYMO PRINCIPAI
}

\author{
Gabija Pancekauskaite $\dot{e}^{1,2}$, Ingrida Melnikienè $\dot{e}^{1,2}$, Goda Camille Mickevičiūtè ${ }^{1}$, \\ Kristina Ganzijeva ${ }^{1,2}$, Lina Jankauskaite ${ }^{1,2,3}$ \\ ${ }^{1}$ Lietuvos sveikatos moksly universiteto Medicinos fakultetas, \\ ${ }^{2}$ Lietuvos sveikatos moksly universiteto ligoninès Kauno kliniku Vaiku ligu klinika, \\ ${ }^{3}$ Lietuvos sveikatos moksly universiteto Fiziologijos ir farmakologijos institutas
}

Raktažodžiai: ūminis skausmas, vaikų skausmo vertinimas, vaikų skausmo fiziologija.

\section{Santrauka}

Skausmas yra viena dažniausių kreipimosi ị vaikų skubios pagalbos skyrių priežasčių. Dauguma vaikų patiria skausmingas diagnostikos procedūras, kurios kelia baimę, skausmą ir nerimą. Vaiko patiriamas skausmas dažnai neužtektinai pripažistamas, netiksliai nustatomas jo stiprumas, todèl neužtikrinamas adekvatus nuskausminimas.

Tikslas - nustatyti vaikų skausmo pojūčio skirtumus nuo suaugusiujų, pristatyti skausmo vertinimo skales, padedančias atpažinti ir tiksliau ịvertinti vaikų patiriamą skausmą, siekiant adekvataus nuskausminimo. Tyrimo objektas ir metodika. Atlikta sisteminè literatūros apžvalga vaikų patiriamo ūminio skausmo tema, naudojantis paieškos sistema Pubmed ir Google Scholar duomenų bazėse. Rasta 427 publikacijos. Analizei atrinkti 9 straipsniai, aprépiantys 2010-2019 metų laikotarpi.

Rezultatai. Sisteminèje literatūros apžvalgoje išnagrinèti 9 straipsniai. Itraukti straipsniai nagrinejjantys kūdykių ir vaikų skauso neurofiziologinius ypatumus. Aptartos įvairaus amžiaus vaikams taikomos skausmo vertinimo skalès.

Išvados. Vaikų skausmo neurofiziologiniai ypatumai labai skiriasi nuo suaugusiųur. Nepakankamas nuskausminimas gali lemti ilgalaikius skausmo suvokimo pokyčius ir sukelti specifines su tuo susijusio elgesio išraiškas. Pastaraisiais metais daugèja duomenų, nurodančių kūdikių-vaikų-paauglių skausmo efektyvesnio ịvertinimo bei gydymo poreikị. Nepaisant turimų priemonių bei specifinių skalių, nepakankamai adekvatus skausmo vertinimas lemia nepakankamą ar netinkamą nuskausminimą. Geresnei skausmo kontrolei užtikrinti svarbu mokyti medicinos personalą bei vaikų artimuosius, kaip laiku ir kuo tiksliau atpažinti vaiko jaučiamą skausmą bei jo stiprumą.

\section{İvadas}

Kasdien ị vaikų skubios pagalbos skyrių (toliau - VSPS) kreipiamasi dèl vaikų ūminio įvairios lokalizacijos ir kilmès skausmo. Daugumai vaikų atliekamos skausmingos diagnostikos procedūros, tokios kaip periferinès venos punkcija ir kt. Šios dažnai netikètos procedūros dar labiau didina stresą ir nerimą, susijusị su patiriama būkle, sukelia negatyvius jausmus bei formuoja nemalonią patirtị. VSPS darbo specifika - greitas darbo tempas, triukšminga aplinka, didelè medicinos darbuotojų kaita, skirtingas personalo pasirengimas ir patirtis teikia šiai sveikatos ịstaigai išskirtinị atspalvị ir gali dar labiau didinti mažojo paciento ir jo artimujų stresą bei nerimą [1].

Tarptautinės skausmo tyrimo asociacijos (toliau - TSTA) duomenimis, skausmas yra nemaloni sensorinè bei emocinè patirtis, susijusi su esama ar galima audinių pažaida. Vaikų patiriamas skausmas yra ypatinga situacija, reikalaujanti ivvertinti ne tik skausmo priežastị ar pobūdi, bet ir vaiko amžių, raidos lygi, bendravimo galimybes, skausmo supratimą bei skausmo patirtį. Vertinant vaikų būklę, visada svarbu užtikrinti tèvų buvimą šalia, nes būtent šis veiksnys gali tiesiogiai ar netiesiogiai prisidèti prie vaiko patiriamo skausmo, esamos būklès sukeliamo streso bei nerimo. Vaikų skausmo suvokimas labai skiriasi nuo suaugusiujų. Jis susijęs su vaiko raida, skausmo patirtimi, psichologiniais bei elgesio veiksniais, todèl vaikų skausmą sunkiau ịvertinti, nei suaugusiujų̧. Ivairaus amžiaus vaikų skausmui matuoti sukurtos skalès ir priemonès. VSPS darbuotojai turi mokèti atpažinti įvairaus amžiaus vaikų skausmo simptomus ir nustatyti, ar vaikų elgesio ar fiziologinių parametrų pokyčiai sukelti skausmo, 


\section{4}

ar kitų veiksnių [1].

Tyrimo tiks-

las - nustatyti vaiku skausmo pojūčio skirtumus nuo suaugusiujų, pristatyti skausmo vertinimo skales, padedančias atpažinti ir tiksliau įvertinti vaiku patiriamą skausmą, siekiant adekvataus nuskausminimo.

\section{Tyrimo objektas ir metodika}

Tyrimo objektas mokslinèse duomenu bazèse rastos publikacijos. Literatūros paieška buvo atliekama PubMed, Google Scholar. Paieškai buvo naudojami raktiniai žodžiai, atitinkantys tyrimo tikslą. Atlikus pradinę paiešką iš viso buvo rastos 427 publikacijos, iš kurių susiaurinta paieška ìvedus papildomus kriterijus: straipsniai anglų kalba, žmogaus tyrimai, tik nemokami straipsniai, straipsniai ne vèlesni nei 10 metur, liko 8 straipsniai ir 1 internetinis šaltinis.

\section{Tyrimo rezultatai}

Vaiko patiriamas skausmas dažnai nepakankamai ịvertinamas, netiksliai nustatomas jo sunkumas, todèl neužtikrinamas adekvatus nuskausminimas. Netikslus skausmo lygio nustatymas susijęs su patofiziologiniais skausmo mechanizmais vaikų amžiuje, paplitusia nuomone, kad „vaikui taip neskauda, kaip skauda suaugusiajam“ ir pan. Baimė naudoti farmakologines priemones ar žinių ir patirties stoka vertinti bei parinkti nuskausminimo metodą, kliudo skirti tinkamą skausmą malšinantị gydymą vaikams. İvairūs mitai, įsitikinimai ir prietarai, asmeninès vertybès (,,kančia taurina“, „,per kančias - i žvaigždes“, „,kentèk, nes tu didelis“, „kūdikis nejaučia skausmo“ ir kt.) dažnai lemia nepakankamą skausmo ịvertinimą bei netinkamą analgeziją. Adekvatus nuskausminimas yra labai svarbus, ypač kūdikysteje ir ankstyvoje vaikysteje. Nepakankamas nuskausminimas gali lemti ilgalaikius skausmo suvokimo pokyčius ir sukelti specifines su tuo susijusio elgesio išraiškas. Stresas bei diskomfortas, patiriamas ịvairių medicininių procedūrų metu, turi ilgalaikị neigiamą poveikị pacientams bei jų artimiesiems [2]. Tai gali lemti valgymo ir miego sutrikimus, bloginti bendravimo ịgūdžius, sukelti potrauminị stresą, ar nepagrịstą baimę. Sveikatos specialistai yra atsakingi už adekvatų nuskausminimą tinkamu laiku bei baimès ir nerimo sumažinimą, siekiant užtikrinti paciento saugumą. Pastaruoju metu vis dažniau kalbama apie nefarmakologinius nuskausminimo metodus. Tai esminè nuskausminimo dalis, ypač svarbi VSPS. Tinkamai parinktos ir naudojamos nefarmakologinès skausmo malšinimo priemonès gali ne tik padèti vaikams įveikti su procedūromis ar būkle susijusią baimę bei stresą, bet ir sumažinti nuskausminamujų dozes, o dažnai ir išvengti medikamentinio nerimo malšinimo.

Vaikų ūminio skausmo neurofiziologiniai ypatumai. Skausmas prasideda nuo nociceptorių dirginimo. Nociceptoriai - skausmui jautrios laisvosios nervinès galūnės, esančios daugelyje kūno audinių. Skausminis dirgiklis pažeidžia audinius ir netiesiogiai aktyvina nociceptorius, vykstant ląstelių ir audinių reakcijoms, kurių metu išsiskiria cheminès medžiagos (kalio jonai, serotoninas, bradikininas, histaminas, prostaglandinai, leukotrienai, medžiaga P), dirginančios laisvąsias nervines galūnes ir mechaninį ar cheminị dirginimą pakeičiančios veikimo potencialu, nuo kurio prasideda skausmo plitimo kelias. Skausmo impulsas šių neuronų aksonais kyla ị nugaros smegenis, ten sudaro sinapses su užpakalinių ragų neuronais, kuriais skausmas kyla aukštyn per priekinių šoninių laidų sistemą i gumburą. Nugaros smegenų užpakalinių ragų neuronų aksonai sudaro sinapses su ventralinių pamatinių gumburo branduolių neuronais, kurių

1 lentelè. Vaikų skausmo plitimo keliai ir atsakas

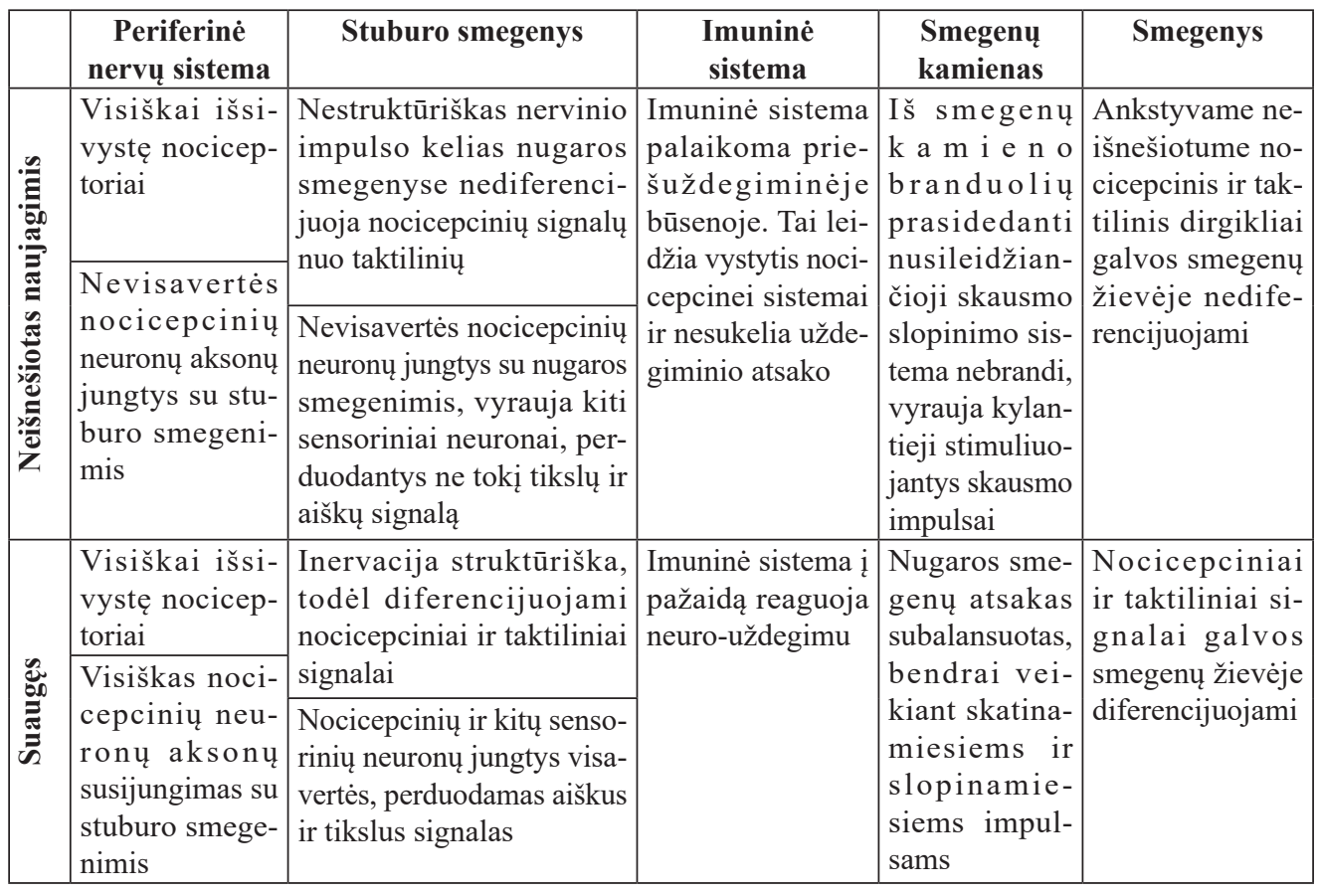


aksonais skausmo impulsas perduodamas ị pirminę ir antrinę somatosensorinę žievę. Galvos smegenyse nocicepciniai impulsai kartu su emociniu ir pažintiniu komponentais suformuoja sąmoningą skausmo jutimą [3].

Skausmo kelias vaiko organizme turi tam tikrų ypatumų, kurie lemia kitoki skausmo jutimą ir suvokimą. Nocicepcinè skausmo sistema funkcionuoja nuo 20-osios nëštumo savaitės, tad neteisinga manyti, kad patys mažiausi pacientai skausmo nejaučia ar ji jaučia silpniau. Kad suprastume skausmo plitimo skirtumus, patogu lyginti suaugusiojo ir

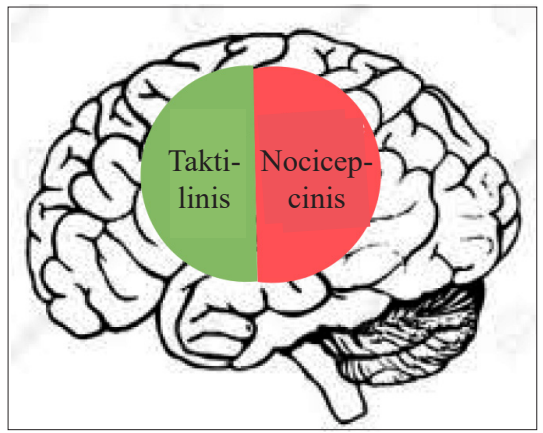

1 pav. Suaugusio žmogaus skausmo jutimas galvos smegenyse

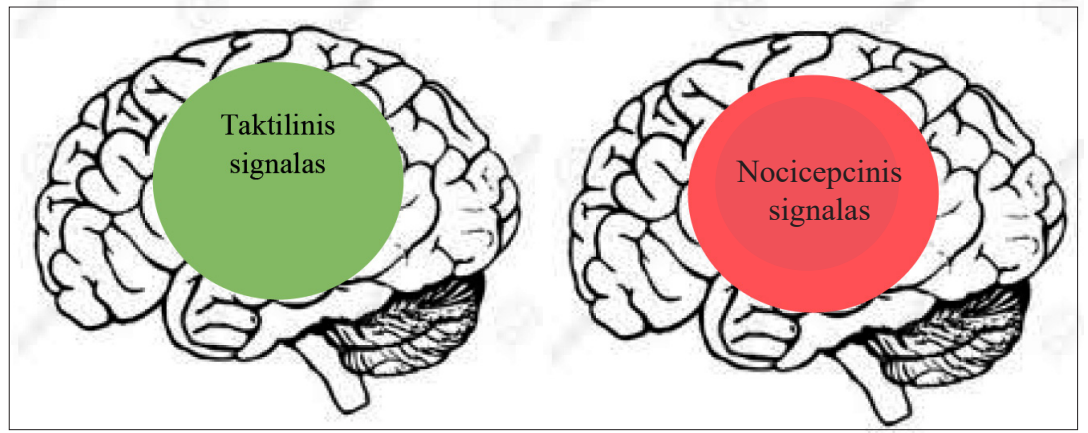

2 pav. Skausmo jutimas neišnešioto naujagimio smegenyse

2 lentelè. Skirtingo amžiaus vaikų skausmo išraiška

\begin{tabular}{|c|c|c|c|c|}
\hline Amžius & Skausmo supratimas & Elgesys & Kalba & $\begin{array}{c}\text { Skausmo } \\
\text { vertinimas }\end{array}$ \\
\hline 6 mèn. & $\begin{array}{l}\text { Skausmo nesupranta, rea- } \\
\text { guoja i tėvų nerimą }\end{array}$ & $\begin{array}{l}\text { Grimasos, bendri kūno } \\
\text { judesiai }\end{array}$ & Verksmas & \\
\hline 6-12 mèn. & $\begin{array}{l}\text { Yra skausmo atmintis, rea- } \\
\text { guoja ị tėvų nerimą }\end{array}$ & $\begin{array}{l}\text { Grimasos, dirglumas, } \\
\text { neramumas, refleksiškai } \\
\text { atsitraukia nuo skausmo } \\
\text { dirgiklio } \\
\end{array}$ & Verksmas & NIPS/FLACC \\
\hline $1-3 \mathrm{~m}$. & $\begin{array}{l}\text { Nesupranta, kas ir kodėl } \\
\text { sukelia skausmą }\end{array}$ & $\begin{array}{l}\text { Tikslingai traukiasi nuo } \\
\text { dirgiklio, priešinasi visu } \\
\text { kūnu, agresyvus elgesys }\end{array}$ & $\begin{array}{l}\text { Verksmas, rèkimas, } \\
\text { negali apibūdinti } \\
\text { skausmo intensyvumo, } \\
\text { pobūdžio }\end{array}$ & FLACC \\
\hline $3-6 \mathrm{~m}$. & $\begin{array}{l}\text { Supranta skausmą, bet jo } \\
\text { nesieja su liga, gali sieti su } \\
\text { trauma. Nesupranta, kaip } \\
\text { skausminga procedūra gali } \\
\text { padèti pasveikti }\end{array}$ & $\begin{array}{l}\text { Aktyvus fizinis priešini- } \\
\text { masis, agresyvus elge- } \\
\text { sys, atsakas ị skausmą ir } \\
\text { fizinis, ir žodinis }\end{array}$ & $\begin{array}{l}\text { Gali apibū dinti } \\
\text { skausmą, jo vietą ir } \\
\text { intensyvumą. Gali } \\
\text { skausmą neigti }\end{array}$ & $\begin{array}{l}\text { FLACC/ } \\
\text { FPS-R }\end{array}$ \\
\hline 7-9 m. & $\begin{array}{l}\text { Nesupranta skausmo prie- } \\
\text { žasčių, tačiau supranta } \\
\text { paprastas sąsajas tarp } \\
\text { skausmo ir ligos, skaus- } \\
\text { mingų procedūru įtaką pa- } \\
\text { sveikimui }\end{array}$ & $\begin{array}{l}\text { Derybos, pasyvus prie- } \\
\text { šinimasis, ịsitempęs } \\
\text { kūnas, emocinis atsi- } \\
\text { traukimas }\end{array}$ & $\begin{array}{l}\text { Gali tiksliai nurodyti } \\
\text { skausmo vietą, in- } \\
\text { tensyvumą, pobūdį ir } \\
\text { sąsają su kūno dalimis }\end{array}$ & \multirow{3}{*}{$\begin{array}{l}\text { FPS-R/VAS/ } \\
\text { CAS }\end{array}$} \\
\hline $10-12 \mathrm{~m}$. & $\begin{array}{l}\text { Geresnis santykio tarp ịvy- } \\
\text { kio ir skausmo supratimo }\end{array}$ & $\begin{array}{l}\text { Gali apsimesti, jog jiems } \\
\text { viskas gerai, kad atro- } \\
\text { dytų drąsūs }\end{array}$ & $\begin{array}{l}\text { Geba tiksliau apibū- } \\
\text { dinti skausmo vietą, } \\
\text { intensyvumą }\end{array}$ & \\
\hline $13-18 \mathrm{~m}$. & $\begin{array}{l}\text { Daugialypis skausmo ir jo } \\
\text { priežasčių suvokimas. At- } \\
\text { pažįsta kiekybinius ir ko- } \\
\text { kybinius skausmo bruožus }\end{array}$ & $\begin{array}{l}\text { Nori elgtis kaip suaugę, } \\
\text { gali nesiskųsti gavę } \\
\text { užuominų iš personalo }\end{array}$ & $\begin{array}{l}\text { Imantresni apibūdini- } \\
\text { mai siejami su patir- } \\
\text { timi. Mano, kad visi } \\
\text { supranta jų skausmą } \\
\text { todèl galima apie jị } \\
\text { nekalbėti }\end{array}$ & \\
\hline
\end{tabular}


neišnešioto naujagimio skausmo plitimo kelius (1 lentelè). Tuomet skirtumai ryškiausi, o vaikui augant ir nervų sistemai bręstant, skausmo kelias panašèja ị suaugusiojo [4]. Ir suaugusiojo, ir neišnešioto naujagimio nociceptoriai yra visiškai išsivystę, tačiau neišnešioto naujagimio aksonų jungtys su nugaros smegenimis nèra visavertès. Suaugusiojo organizme pirmujų skausmo signalo plitimo kelio neuronų aksonų galūnèlès išsidèsto pagal tam tikrą struktūrą. Neišnešioto naujagimio stuburo smegenyse skausmas plinta nestruktūriškai [5], t.y. kelių tipų neuronų aksonai II užpakalinių nugaros smegenų ragų plokštelèje beveik sutampa, todèl išnyksta pavojingo ir nepavojingo stimulo diferenciacija $[5,6]$. Kadangi nocicepciniai neuronai nèra visavertiškai įtraukiami ị skausmo plitimo sistemą, joje vyrauja kiti sensoriniai neuronai. Dèl šių priežasčių neišnešioto naujagimio nervų sistemos taktiliniai ir nocicepciniai dirginimai nediferencijuojami, o skausmo signalas ne toks tikslus ir aiškus. Dirgiklis naujagimysteje intensyvina neuroimuninị atsaką, stiprindamas nocicepcinius refleksus nugaros smegenyse ir mikroglijos reakcijas, tačiau neurouždegimo nesukelia, reakcijos nutrūksta ikiuždegiminèje fazèje, o suaugusiojo organizme imuninè sistema ị pažaidą reaguoja neurouždegimu [5]. Tyrimuose su gyvūnais pastebèta, kad skausmo aktyvuota mikroglija naujagimystèje, net ir nutrūkus reakcijai ikiuždegiminèje fazèje, palieka ilgalaikius nugaros smegenų pokyčius, kurie gali lemti suaugusiojo hiperalgeziją ir lètinio skausmo vystymąsi $[7,8]$. Nugaros smegenų lygmenyje skausmo signalas moduliuojamas ir skatinamaisiais, ir slopinamaisiais signalais. Skausmo slopinamųjų laidų sistema iš smegenų kamieno branduolių plinta ị nugaros smegenis. Siūlès branduolių neuronų, esančių smegenų kamiene, aksonai, išskiriantys serotoniną, ir melsvosios dėmès neuronų aksonai, išskiriantys noradrenaliną, aktyvina užpakalinių ragų tarpinius neuronus, kurie slopina skausmo signalu perdavimą nugaros smegenyse. Naujagimio slopinamoji skausmo sistema yra neefektyvi, nes tarpiniai neuronai nebrandūs, o noradrenalino ir serotonino išsiskyrimas vyksta lečiau, nei suaugusiojo organizme [8]. Suaugusiojo galvos smegenų žievejje taktilinis ir nocicepcinis dirgiklis diferencijuojami (1 pav.). Ankstyvojo neišnešiotumo periode nocicepciniai ir taktiliniai signalai smegenų žievèje nediferencijuojami, todèl ir skausminis, ir

3 lentelè. Naujagimių ir kūdikių skausmo skalè bei jos vertinimas

\begin{tabular}{|l|l|l|l|}
\hline & \multicolumn{1}{|c|}{ 0 balų } & \multicolumn{1}{c|}{ 1 balas } & 2 balai \\
\hline Veido išraiška & Atsipalaidavęs & İsitempęs & \\
\hline Verksmas & Nėra & Verkšlenimas & Stiprus \\
\hline Kvėpavimas & Normalus & Pasikeitęs & \\
\hline Rankos & Atsipalaidavusios & Sulenktos/ištiestos & \\
\hline Kojos & Atsipalaidavusios & Sulenktos/ištiestos & \\
\hline Budrumas & Miegantis/ramus & Neramus & \\
\hline
\end{tabular}

neskausminis dirgiklis neišnešiotam naujagimiui sukelia toki pat jutimą (2 pav.). Naujagimiui bręstant, signalo plitimas darosi vis labiau specifiškas dirgikliui [5]. Vaiko organizme skausmo plitimas yra kitoks ir dèl nervinių skaidulų struktūros skirtumų. Skausmo impulsai plinta A $\delta$ (mielinizuotomis) ir C (nemielinizuotomis) skaidulomis. Nors vaikų organizme mielinizacija nėra pasibaigusi, tai nereiškia, jog vaikai nejaučia skausmo ar jaučia ji silpiau. Nevisiška mielinizacija nulemia léčiau sklindantį, bet ne silpnesnic, skausmo signalą, o lètesnį impulso plitimą kompensuoja trumpesnis nervinio impulso kelias vaikų nervų sistemoje [8].

Vaikų ir suaugusiųjų nocicepcinè sistema yra skirtinga. Vaikų organizme nociceptorių skaičius, tenkantis vienam kvadratiniam kūno paviršiaus metrui, yra didesnis, nei suaugusiujų. Didesnis ir neuromediatorių kiekis, galintis lemti padidejusi jautrumą skausmui. Skausmo signalas vaiko organizme yra intensyvesnis ir trunka ilgiau, lyginant su suaugusiais. Dèl vaikų nervų sistemos plastiškumo ir nocicepcinès sistemos ypatumų, užsitęsęs ar pasikartojantis skausmas ankstyvame amžiuje didina neuronų žūties ar jų funkcijos sutrikimų riziką $[4,8]$. Preparatai, malšinantys skausmą, taip pat gali neurotoksiškai veikti vaiko organizmą. Ir skausmas, ir jo mažinimo priemonès gali toksiškai veikti besivystančią kūdikio ar vaiko nervų sistemą. Dėl šių priežasčiu skausmas, jo vertinimas ir malšinimas naujagimysteje, kūdikysteje ir vaikystèje yra labai svarbi, tačiau nesulaukianti pakankamo dèmesio, tema.

Vaikų ūminio skausmo matavimo priemonès. VSPS atliekamos procedūros dažnai yra skausmingos, netikètos, nemalonios, sukeliančios neigiamas emocijas ir paliekančios blogus prisiminimus, kurie turi itakos ateities vizitams ir

4 lentelè. FLACC skausmo vertinimo skalè

\begin{tabular}{|c|c|c|c|}
\hline & \multicolumn{3}{|c|}{ Balai } \\
\hline & $\mathbf{0}$ & 1 & 2 \\
\hline Veidas & $\begin{array}{l}\text { Nėra konkrečios } \\
\text { išraiškos ar šyp- } \\
\text { sosi }\end{array}$ & $\begin{array}{l}\text { Protarpinės išraiš- } \\
\text { kos, susiraukimas, } \\
\text { nebendrauja }\end{array}$ & $\begin{array}{l}\text { Dažnai ar nuolat } \\
\text { susiraukęs, virpa } \\
\text { smakras, lūpos } \\
\text { stipriai suspaus- } \\
\text { tos }\end{array}$ \\
\hline Kojo & $\begin{array}{l}\text { Normali padėtis } \\
\text { ar atsipalaidavęs }\end{array}$ & $\begin{array}{l}\text { Nuolat juda, ịsi- } \\
\text { tempusios }\end{array}$ & $\begin{array}{l}\text { Spardosi ar pri- } \\
\text { trauktos }\end{array}$ \\
\hline $\begin{array}{l}\text { Akty- } \\
\text { vumas }\end{array}$ & $\begin{array}{l}\text { Normalioje po- } \\
\text { zicijoje, judesiai } \\
\text { laisvi }\end{array}$ & $\begin{array}{l}\text { Rangosi, riečiasi } \\
\text { i priekị, atgal, ịsi- } \\
\text { tempęs }\end{array}$ & $\begin{array}{l}\text { Išsilenkęs lanku, } \\
\text { įsitempęs, krūp- } \\
\text { čioja }\end{array}$ \\
\hline $\begin{array}{l}\text { Verks- } \\
\text { mas }\end{array}$ & Neverkia & $\begin{array}{l}\text { Dejuoja, verkš- } \\
\text { lena, kartais pasi- } \\
\text { skundžia }\end{array}$ & $\begin{array}{l}\text { Nuolat verkia, } \\
\text { kūkčioja, rėkia, } \\
\text { dažnai skundžiasi }\end{array}$ \\
\hline $\begin{array}{l}\text { Nura- } \\
\text { mini- } \\
\text { mas }\end{array}$ & $\begin{array}{l}\text { Ramus, atsipa- } \\
\text { laidavęs }\end{array}$ & $\begin{array}{l}\text { Nurimsta palietus, } \\
\text { apkabinus, pakal- } \\
\text { binus, išblaškomas }\end{array}$ & $\begin{array}{l}\text { Sunkiai nurami- } \\
\text { namas }\end{array}$ \\
\hline
\end{tabular}




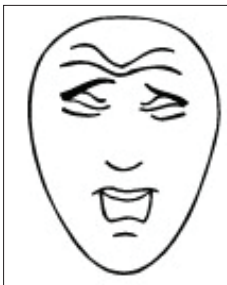

10

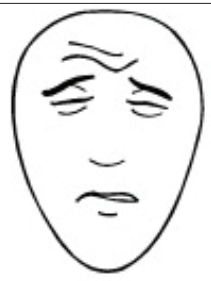

8



6



4

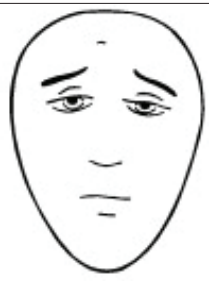

2

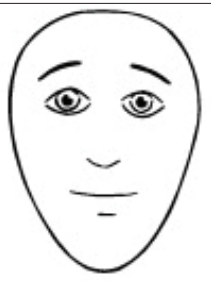

0
3 pav. Veidukų skalè

vaiko baimėms. Dėl šių priežasčių svarbu skausmą teisingai ivvertinti ir malšinti. Ūminio skausmo malšinimo ir vertinimo principai bendri ir suaugusiems, ir vaikams, tačiau vaikų skausmo vertinimą sunkina jų amžiaus, raidos, pažinimo ir bendravimo ịūdžių, ankstesnès neigiamos patirties ir tėvų bei vaiko išankstinių nuostatų skirtumai, o dalis skausmo malšinimui vartojamų preparatų netinkami vaikams.

Skirtingo amžiaus vaikai skausmą supranta ir išreiškia skirtingai (2 lentelè), todèl skausmo vertinimas priklauso nuo vaiko amžiaus. Pačių mažiausiųjų pacientų (iki vienerių metų) skausmo vertinimui rekomenduojama Naujagimių ir kūdikių skausmo skalè (angl. Neonatal infant pain scale, toliau - NIPS). Vertinama veido išraiška, verksmas, kvėpavimas, rankų ir kojų padètis, budrumas. Didžiausia balų suma yra 7, tačiau surinkus 3, reikètų pagalvoti, jog naujagimiui ar kūdikiui skauda (3 lentelè).

Pacientų nuo 2 mènesių iki 7 metų skausmo vertinimui galima naudoti veido, kojų, aktyvumo, verksmo, nuraminimo skalę (angl. Face, legs, activity, cry and consolability scale, toliau - FLACC), 4 lentelè. Miegantis pacientas turètų būti stebimas daugiau nei 5 minutes ir tik tuomet ivvertinamas, o aktyvų pacientą reikètų vertinti 1-5 minutes. 1-3 balai reiškia, jog pacientas jaučia lengvą diskomfortą, 4-6 - vidutinio stiprumo skausmą, 7 ir daugiau - stiprų diskomfortą ir (ar) stiprų skausmą. Didžiausia balų suma - 10. Pataisyta veidukų skausmo skale (angl. Faces pain scale - revised, toliau FPSR) gali būti naudojama vertinti 4-16 metų vaikų skausmui. Vaikui parodoma veidukų skalè (3 pav.). Paaiškinama, kad veidukas dešinèje rodo, kad nieko neskauda, veidukuose iš dešinès ị kairę rodomas skausmo stiprèjimas iki stipriausio (paskutinis veidukas kairejje). Tuomet vaiko prašoma parodyti jo skausmo stiprumą apibūdinantị veiduką. Kiekvienas veidukas atitinka balų skaičių $(0,2,4,6,8,10)$. Nustatyta, jog šie balai savo reikšme artimi vaizdo analogijos skalès (toliau - VAS) balams, todèl veidukų skausmo skalè yra patogi mažesniems vaikams, ar tiems, kuriems sunku suprasti VAS. Vaizdo analogijos skale - paprastas ir populiarus metodas, nereikalingas nei papildomų priemonių, nei ilgo paciento stebejjimo, tačiau yra tinkamas tik vaikams nuo 7-8 metų. Ant popieriaus lapo nubrèžiama atkarpa (rekomenduojama
$10 \mathrm{~cm}$ ), kurios vienas galas reiškia skausmo nebuvimą, o kitas - nepakeliamą skausmą. VAS skalès rezultatas užrašomas milimetrais ar centimetrais. Šios skalès trūkumas - nèra sutartinės reikšmės, kada skausmą laikyti lengvu, vidutiniu ar stipriu, todėl sunku spręsti apie tolimesni gydymą. Viena siūlomų VAS interpretacijų - 0-4 $\mathrm{mm}$ - pacientas skausmo nejaučia, 5-44 mm - nestiprus skausmas, 45 - $74 \mathrm{~mm}$ vidutinis skausmas, 75-100 mm - stiprus skausmas $(1,9)$. Kaip vaikui artimesnè VAS alternatyva, šiuo metu siūloma spalvų analogijos skale (angl. Color analog scale, toliau CAS). Tyrime, atliktame su 6-17 metų vaikais, patyrusiais raumenų ar skeleto traumą, pastebėta, kad CAS vaikams buvo lengviau suprantama, didesné jų dalis sugebejjo ịvertinti skausmą pagal šią skalę [10]. CAS principas toks pat, kaip VAS, tačiau $10 \mathrm{~cm}$ atkarpoje keičiasi spalvos. Vaikui paaiškinama, kuri spalva reiškia didžiausią skausmą, o kuri - mažiausią. Spalvos padeda vaikui geriau suvokti gydytojo ar slaugytojo klausimą ir lengviau suformuluoti atsakymą. Skausmo verte užrašoma milimetrais ar centimetrais.

Nepaisant skausmo vertinimo priemonių gausos, šiuo metu nèra vieningai pripažinto vaikų skausmo vertinimo metodo skubios pagalbos skyriuje ar poliklinikoje. Kuris metodas bus taikomas, priklauso nuo gydytojo ar slaugytojo, vaiko amžiaus, raidos, sąmonès būklès, aplinkybių.

\section{Išvados}

1. Skausmas yra viena dažniausių kreipimosi ị vaikų skubiosios pagalbos skyrių priežasčių. Skausmo valdymo klausimas aktualus kur kas didesniam VSPS pacientų srautui, nes daugumai vaikų atliekamos invazinès procedūros, tokios kaip venos punkcija ir kt., kurios didina mažųjų pacientų baimę, skausmą ir nerimą.

2. Vaikų skausmo pojūtis labai skiriasi nuo suaugusiųų dèl neurofiziologinių ypatumų. Šie skirtumai ryškiausi lyginant naujagimius ir suaugusiuosius. Pastaraisiais metais daugèja duomenų bei gairių, nurodančių poreikị efektyvesniam kūdikių-vaikų-paauglių skausmo ịvertinimui bei gydymui.

3. Nepaisant turimų priemonių bei specifinių skalių, skausmo vertinimas dar vis nèra pakankamai adekvatus ir 
tai sąlygoja nepakankamą ar netinkamą nuskausminimą. Siekiant užtikrinti geresnę skausmo kontrolę, svarbu mokyti medicinos personalą bei vaikų artimuosius laiku ir kuo tiksliau atpažinti vaiko jaučiamą skausmą bei įvertinti jo stiprumą. Tam tikslui svarbu pritaikyti vaiko amžiui tinkamiausią skausmo skalę, atsižvelgti į ankstesnę su diagnostikos ar gydymo procedūromis susijusią patirtį, kūdikio-vaiko-paauglio individualias savybes, esamą būklę, gretutines ligas, bendravimo galimybes bei patiriamą nerimą.

\section{Literatūra}

1. Srouji R, Ratnapalan S, Schneeweiss S. Pain in children: assessment and nonpharmacological management. Int J Pediatr 2010;2010:1-11. http://dx.doi.org/10.1155/2010/474838 https://doi.org/10.1155/2010/474838

2. Moore ER, Bennett KL, Dietrich MS, Wells N. The effect of directed medical play on young children's pain and distress during burn wound care. J Pediatr Heal Care 2015;29(3):265-273. https://doi.org/10.1016/j.pedhc.2014.12.006

3. Kèvelaitis E., Illert M., Hultborn H. Žmogaus fiziologija, 2-as leidimas. KMU leidykla, 2006;78-81.

4. Lundeberg S, Lundeberg T. Pain in infants and children - physiological background and clinical aspects. Acupunct Relat Ther 2013;1(4):46-49.

https://doi.org/10.1016/j.arthe.2013.05.002

5. SickKids - hospital. https://www.sickkids.ca/index.html

6. Vinall J, Grunau RE. Impact of repeated procedural pain-related stress in infants born very preterm. Pediatr Res 2014;75(5):584587.

https://doi.org/10.1038/pr.2014.16

7. Beggs S, Currie G, Salter MW, Fitzgerald M, Walker SM. Priming of adult pain responses by neonatal pain experience: maintenance by central neuroimmune activity. Brain 2012;135(2):404-417.

https://doi.org/10.1093/brain/awr288

8. Hatfield L. Neonatal pain: what's age got to do with it? Surg Neurol Int 2014;5(14):479.

https://doi.org/10.4103/2152-7806.144630

9. Hawker GA, Mian S, Kendzerska T, French M. Measures of adult pain: Visual analog scale for pain (VAS Pain), Numeric rating scale for pain (NRS Pain), McGill pain questionnaire (MPQ), Short-Form McGill pain questionnaire (SF-MPQ), Chronic pain grade scale (CPGS), Short Form-36 bodily pain scale (SF-36 BPS), and Measure of intermittent and constant osteoarthritis pain (ICOAP). Arthritis Care Res 2011;63(11):240-252.

https://doi.org/10.1002/acr.20543
10. Le May S, Ballard A, Khadra C, et al. Comparison of the psychometric properties of 3 pain scales used in the pediatric emergency department: Visual analogue scale, faces pain scale-revised, and colour analogue scale. Pain 2018;159(8):1508-1517.

https://doi.org/10.1097/j.pain.0000000000001236

\section{CHILDREN'S ACUTE PAIN:}

IT'S CHARACTERISTICS, NEUROPHYSIOLOGICAL ASPECTS AND EVALUATION

\section{G. Pancekauskaitė, I. Melnikienė, G.C. Mickevičiūtė,} K. Ganzijeva, L. Jankauskaitè

Keywords: acute pain, pediatric pain evaluation, physiology of pediatric pain.

Summary

Pain is one of the most common reasons for contacting a pediatric emergency department. Most children require painful diagnostic procedures which increase patient fear, pain, and anxiety. The pain experienced by the child is often underestimated, the intensity of the pain is not accurately evaluated and adequate analgesia is not guaranteed.

We aimed to analyze the differences between pediatric and adult pain and to describe pain evaluation scores regarding a better pain treatment.

Objectives and methods of the study: we conducted a literature analysis with regard to acute pediatric pain. The search was performed in PubMed and Google Scholar data basis. The initial search returned 427 publications. Only 9 of them were included in the final analysis.

Results: nine articles were analyzed in this literature review. These articles evaluated neurophysiological aspects of pediatric and adult pain. Moreover, various pain evaluation scales used according to child's age are discussed in this study.

Conclusions: Children feel pain differently compared to adults in terms of their neurophysiological characteristics. Insufficient analgesia can contribute to long-term changes in the perception of pain and can lead to specific behaviors associated with it. Recently, there has been increasing evidence pointing to the need for more effective pain assessment and treatment of infants/children/adolescents. Despite the available tools and specific scales, pain assessment is still not adequate and results in insufficient or inappropriate pain relief. In order to provide better pain control, it is important to train medical staff and children's relatives how to recognize the child's pain and severity in a timely and accurate manner.

Correspondence to: Lina.Jankauskaite@1smuni.lt

Gauta 2020-04-19 